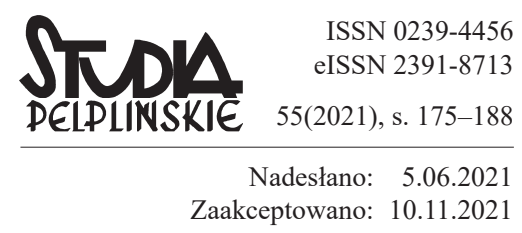

KS. ANDRZEJ MEGGER

Katolicki Uniwersytet Lubelski Jana Pawła II w Lublinie

andrzej.megger@gmail.com

ORCID: orcid.org/0000-0001-5675-9129

\title{
BISKUP KAZIMIERZ JÓZEF KOWALSKI (1896-1972) JAKO PREKURSOR ODNOWY LITURGICZNEJ W DIECEZJI CHEŁMIŃSKIEJ, W ŚWIETLE „ORĘDOWNIKA DIECEZJI CHEŁMIŃSKIEJ"
}

DOI: http://dx.doi.org/10.12775/SPLP.2021.010

\section{Streszczenie}

Biskup Kazimierz Józef Kowalski był pierwszym w historii diecezji chełmińskiej ordynariuszem uczestniczącym w pracach soboru powszechnego. Jako konsultor Komisji Liturgicznej Drugiego Soboru Watykańskiego brał czynny udział w przygotowaniu reformy liturgii i rozumiał jej istotę i cele. Swoje stanowisko prezentował przede wszystkim w różnych formach w „Orędowniku Diecezji Chełmińskiej”, jako urzędowym piśmie Kościoła partykularnego. Biskup Kowalski nauczał o fundamentalnym znaczeniu zasady actuosa participatio dla liturgii, poprzez którą wierni tworzą żywy Kościół, Mistyczne Ciało Chrystusa, oddając chwałę Bogu i uczestnicząc w misterium paschalnym. Realizacją zasady ,aktywnego uczestnictwa" były konkretne zarządzenia wprowadzające duchowieństwo i wiernych w życie Kościoła po soborze. Ordynariusz chełmiński był zarówno strażnikiem Tradycji Kościoła wyrażającej się w lex orandi, jak i mistagogiem, który konsekwentnie wprowadzał powierzoną mu wspólnotę diecezjalną w posoborową rzeczywistość Kościoła objawiającego się w liturgii.

Slowa kluczowe: liturgia, msza św., Drugi Sobór Watykański, actuosa participatio, ruch liturgiczny, diecezja chetmińska 


\title{
BISHOP KAZIMIERZ JOZEF KOWALSKI (1896-1972) AS A PIONEER OF THE DIOCESE OF CHELMNO LITURGICAL RENEWAL
}

\begin{abstract}
The Most Rev. Kazimierz Jozef Kowalski was the first diocesan bishop of Chelmno to participate in an ecumenical council. As a consultant of the conciliar liturgical commission he took an active part in the preparation of the reforms. The bishop was presenting his ideas and opinions in the official diocesan review known as „Oredownik Diecezji Chelminskiej”. A common theme of his articles was the active participation of the faithful in the liturgy, its purpose and normative requirements for clergy and laity. Bishop Kowalski was both a guardian of the liturgical tradition of the Church and a worship moderator of his diocesan flock who was systematically introducing the new celebratory forms.
\end{abstract}

Keywords: liturgy, mass, Second Vatican Council, active participation, liturgical movement, Diocese of Chelmno

Może się wydawać, że dotychczasowa refleksja naukowa nad ruchem liturgicznym, jak i Drugim Soborem Watykańskim, objęła wszystkie jego wymiary. Liczne monografie z różnych dziedzin oraz publikacje o charakterze interdyscyplinarnym prezentują szerokie spektrum zagadnień związanych z munus sanctificandi Kościoła. W dużej mierze jest to prawdą, lecz nadal pozostają przestrzenie dotąd nieeksplorowane naukowo. Należą do nich między innymi szczegółowe zagadnienia związane z Kościołami partykularnymi, w tym podjęta w niniejszym artykule problematyka odnowy liturgii realizowanej przez ordynariusza diecezji chełmińskiej, biskupa Kazimierza Józefa Kowalskiego, który czynnie uczestniczył w obradach komisji soborowych. Z racji powierzonej mu przez Jana XXIII funkcji konsultora Komisji Liturgicznej sprawa odnowy i rozwoju liturgii była mu szczególnie bliska. Jego zaangażowanie zostanie przedstawione w oparciu o urzędowy periodyk diecezji „Orędownik Diecezji Chełmińskiej”, w którym publikowano przemówienia, listy, orędzia i zarządzenia biskupa związane z reformą i odnową liturgii. Najpierw zostanie przedstawione stanowisko biskupa Kowalskiego wobec soboru i jego postanowień odnoszących się do liturgii, a następnie przebieg ich realizacji w diecezji chełmińskiej.

\section{ZNACZENIE DRUGIEGO SOBORU WATYKAŃSKIEGO}

Pochodzący z Gniezna ordynariusz chełmiński sprawował swoją posługę w niełatwych latach 1946-1972, w których musiał najpierw odbudować ogromnie 
zniszczoną wojną diecezję, także w zakresie liturgii i przestrzeni liturgicznej oraz przeprowadzić przez czasy soborowe. Jego bardzo dobre wykształcenie teologiczne i filozoficzne oraz znajomość języków obcych ${ }^{1}$ były zapewne głównymi atutami, dzięki którym był pierwszym w historii diecezji chełmińskiej ordynariuszem uczestniczącym w pracach soboru powszechnego. 22 VIII 1960 roku został mianowany przez Jana XXIII konsultorem Komisji Liturgicznej, której celem było przygotowanie reformy liturgii Drugiego Soboru Watykańskiego². Brał czynny udział w obradach komisji soborowych i jako jeden z siedmiu ordynariuszy uczestniczył we wszystkich sesjach soboru33. Wiązał z nim wielkie nadzieje, czego dał wyraz w orędziu skierowanym do diecezjan przed rozpoczęciem obrad. Powiedział, że „Sobór Powszechny staje się jakoby nowym Zesłaniem Ducha Świętego", dzięki któremu Mistyczne Ciało Chrystusa doświadczy swojej młodości i witalności oraz przyniesie Zbawiciela przyszłym pokoleniom. Te, powtarzające się także później w nauczaniu ordynariusza chełmińskiego sformułowania, wyraźnie ukazywały jego przekonanie, że ukierunkowany duszpastersko sobór przyczyni się do odrodzenia Kościoła, które zapowiadały już wcześniejsze dokumenty papieskie (zwł. encykliki Mystici Corporis Christi z 29 VI 1943 i Mediator Dei z 20 XI 1947). Zinstytucjonalizowany Kościół ze spetryfikowaną liturgią, zawierającą elementy niezupełnie odpowiadające jej naturze (zob. KL 21), wymagał odnowy (aggiornamento), aby Ewangelia mogła być skuteczniej głoszona we współczesnym świecie, przyczyniając się do jedności chrześcijan i ludzkości. W radiowym przemówieniu po III sesji soborowej biskup Kowalski mówił, że na

1 Bp K.J. Kowalski ukończył studia teologiczne w Strasburgu (bakalaureat), obronił pracę doktorską z filozofii w Louvain, studiował we Fryburgu Szwajcarskim i Monachium. Dwukrotnie przeprowadził przewód habilitacyjny w Krakowie i Poznaniu. Zob. M. Mylik, Biskup Kazimierz Józef Kowalski. Z dziejów odnowy neoscholastyki polskiej, Pelplin 2008, s. 56-65. Zob. także: J.E. Liedtke, Miles Christi - Ksiądz Biskup Kazimierz Józef Kowalski, ordynariusz diecezji chetmińskiej, „Studia Elbląskie” XVI (2015), s. 23-41.

2 J.E. Ks. Biskup Ordynariusz mianowany Konsultorem Komisji Soborowej dla spraw Świętej Liturgii, „Orędownik Diecezji Chełmińskiej” 11 (1960), nr 11-12, s. 307 (dalej: ODCh). Zob. M. Mylik, Biskup Kazimierz Józef Kowalski. Z dziejów odnowy neoscholastyki polskiej, Pelplin 2008, s. 69. Komisję utworzył Pius XII w 1948 roku w celu opracowania koncepcji generalnej reformy liturgicznej. Jan XXIII w 1960 roku powołał jej nowy skład, ponieważ celem było stworzenie międzynarodowego gremium złożonego z przedstawicieli pochodzących z krajów, w których ruch liturgiczny znacząco się rozwinął. Zob. A. Krzystek, Przedsoborowe ,drogi” do generalnej reformy liturgicznego Soboru Watykańskiego II, „Colloquia Theologica Ottoniana” 1 (2015), s. 13-16.

3 Zob. Z. Zieliński, Sobór Watykański II. Udziat Polaków, w: 50 rocznica Soboru Watykańskiego II. Sympozjum naukowe. Przemyśl, 8 XI 2012, oprac. J. Łobos, Przemyśl 2013, s. 31; K. Bielawny, Udział biskupów polskich w obradach Soboru Watykańskiego II, „Studia Ełckie” 11 (2009), s. 106-120.

4 Orędzie J.E. Ks. Biskupa Ordynariusza na Nowennę przed Soborem, ODCh 13 (1962), nr 9-10, s. 287-288. 
soborze „działa jedyna w swoim rodzaju miara prawdy, sprawiedliwości i miłości, która znajduje się pod wyraźnym wpływem Ducha Świętego"5. To nadprzyrodzone dzieło, poprzez modlitwy i obrady, umożliwiło Chrystusowi na nowo wkroczenie w dzieje ludzkości, która znajduje się u progu wieku atomowego ${ }^{6}$. Taka, wyżej opisana perspektywa soborowa, stanowi klucz hermeneutyczny do szczegółowych decyzji i działań podejmowanych przez ordynariusza chełmińskiego.

Podczas pobytu w Rzymie propagował myśl soborową, przekazując swoim diecezjanom informacje o przebiegu soboru za pośrednictwem Radia Watykańskiego, listów pasterskich i kierując specjalne orędzia. Przyjęcie pierwszego schematu konstytucji Sacrosanctum Concilium ,z budującą jednomyślnością” interpretuje jako „owoc działania Ducha Świętego"”. Brak wzmianek na ten temat w późniejszych wypowiedziach może wynikać z kontrowersji i problemów, które pojawiły się na dalszych etapach przygotowania tego dokumentu ${ }^{8}$. Raz jeszcze tylko wspomniał bezpośrednio ten dokument, uchwalony 4 XII 1963 roku i obowiązujący od pierwszej niedzieli Wielkiego Postu kolejnego roku, jako opatrznościowy znak dla Kościoła, domagający się dostosowania w poszczególnych krajach?.

Biskup podkreślał pragnienie realizacji nauczania soborowego po uprzedniej, niezbędnej adaptacji Konferencji Biskupów. Postulowane zmiany w liturgii, jak i samą liturgię, postrzegał w szerokiej perspektywie teologicznej, jako kontynuację zbawczego posłannictwa Kościoła (dotąd dominowała prawnicza koncepcja liturgii). Liturgia Kościoła, jak i sam Kościól, ma charakter apostolski ${ }^{10}$. Nie jest ona działaniem człowieka, ale aktualizacją misterium paschalnego Zbawiciela, który jest obecny szczególnie w czynnościach liturgicznych (zob. KL 7) i doprowadza wierzących do pełnego zjednoczenia z sobą w liturgii niebiańskiej. Kościół pielgrzymujący, pisał biskup, przypomina proroka Eliasza, który karmiony przez samego Boga był w stanie udać się w daleką drogę i wypełnić powierzoną mu misję (zob. $1 \mathrm{Krl}$ 19,8). Podobnie Sobór daje prawdziwy i skuteczny pokarm duchowy: „Ciało

5 Poklosie minionych sesji soborowych. Przemówienie J.E. Ks. Biskupa Ordynariusza, wygłoszone w Radio Watykańskim dnia 25 listopada 1964 r., ODCh 15 (1964), nr 11-12, s. 282.

6 Zob. Wielkopostny list pasterski J.E. Ks. Biskupa Ordynariusza, ODCh 14 (1963), nr 1-3, s. 19. Zob. także: Wielkopostny list pasterski J.E. Ks. Biskupa Ordynariusza, ODCh 15 (1964), ns 1-2, s. 13; Wielkopostny list pasterski, ODCh 17 (1966), nr 4-5, s. 19.

7 Przemówienie radiowe J.E. Ks. Biskupa Ordynariusza Kaz. J. Kowalskiego w dniu 19 listopada 1962 roku, ODCh 14 (1963), nr 1-3, s. 17.

8 Przygotowano cztery schematy Konstytucji, które omawiano łącznie na piętnastu posiedzeniach soborowych. Podczas ponad 300 wystąpień wysuwano wiele zastrzeżeń i wnoszono setki propozycji poprawek. Do najbardziej kontrowersyjnych kwestii należały: wprowadzenie języków narodowych do liturgii, przyjmowanie Komunii św. pod obiema postaciami, problem koncelebry i adaptacje liturgiczne oraz uprawnienia ordynariusza. Zob. J. Stefański, Redakcja ,Konstytucji o liturgii świętej” przełomem odnowy życia religijnego w Kościele (1963-2003), „Seminare” 21 (2005), s. 191.

9 Wielkopostny list pasterski J.E. Ks. Biskupa Ordynariusza, ODCh 15 (1964), nr 1-2, s. 14.

10 Wielkopostny list pasterski J.E. Ks. Biskupa Ordynariusza, ODCh 14 (1963), nr 1-3, s. 21. 
Pańskie w Konstytucji o Świętej Liturgii i słowo Boże w Dekrecie o środkach społecznej łączności" ". To stanowi niezbędną i konieczną pomoc w życiu osobistym i społecznym, aby ostatecznie osiągnąć cel - niebiańskie Jeruzalem.

Ordynariusz chełmiński nie podejmował ponadto kwestii formalnych związanych z uchwalaniem i redakcją dokumentów, ale w publikowanych w „Orędowniku Diecezji Chełmińskiej” materiałach często nawiązywał do fundamentalnych założeń odnowy liturgicznej. Jedną z centralnych zasad i jednocześnie celów reformy jest actuosa participatio, czyli doprowadzenie wiernych do pełnego i czynnego uczestnictwa w liturgii (zob. KL 14). Konstytucja dodaje jeszcze kilka dodatkowych określeń tego uczestnictwa, które powinny zostać wzięte pod uwagę w dziele odnowy. Powinno ono być owocne (zob. KL 11), wspólnotowe (zob. KL 21, 27), pobożne (KL 48, 50), doskonałe (zob. KL 55), a także wewnętrzne i zewnętrzne (zob. KL 19). Biskup Kowalski dobrze rozumiał, czym jest ,aktywne uczestnictwo" i jakie posiada znaczenie dla soborowej reformy liturgii. Wykorzystując różne okazje duszpasterskie, w prostej formie nauczał swoich diecezjan. W wielkopostnym liście poświęconym uczestnictwu w życiu Kościoła podkreśla, że fundamentalnym warunkiem trwania we wspólnocie eklezjalnej jest udział w liturgii jako publicznej modlitwie Kościoła powszechnego ${ }^{12}$. Celebrowana liturgia jest bowiem epifanią, szczególnym ujawnieniem się Kościoła (zob. KL 41-42). Dlatego w odniesieniu do Eucharystii, która jest szczytem liturgii, przedstawil, czym jest $\mathrm{w}$ istocie soborowa zasada actuosa participatio. „Nasz udział w tajemnicach Ołtarza powinien być pobożny, nie zamącony żadnymi ziemskimi niepokojami, Bogu jedynie poświęcony. Ma być również uświadomiony, co zakłada żywe zainteresowanie się i dobrą znajomość elementów modlitwy liturgicznej, zwłaszcza okresów roku liturgicznego i tekstów, które Kościół od wieków przedstawia swym wiernym. Udział nasz w tajemnicach Ołtarza ma być koniecznie czynny, czyli powinniśmy współdziałać z kapłanem, który przewodniczy sprawowaniu tych tajemnic. To współdziałanie jednoczy wszystkich uczestników liturgii w jedną, Bożą rodzinę, która pod kierownictwem swego ojca duchowego, zjednoczona i zgodna, składa przez Jezusa Chrystusa Bogu Ojcu wszelką cześć i chwałę"13.

Aktywny udział we Mszy św. jest zatem w istocie udziałem wewnętrznym, polegającym na składaniu ofiary z samego $z$ siebie ${ }^{14}$. Ordynariusz zdawał sobie sprawę z tego, że czynne uczestnictwo przyczynia się do lepszego zrozumienia liturgii i udziału w niej, a prawdziwe, nie tylko zewnętrze, ale i wewnętrzne zaangażowanie, rozwija i umacnia więź eklezjalną. W ten sposób liturgia przyczynia się do nieustannego pogłębiania chrześcijańskiego życia wiernych (zob. KL 1).

11 Wielkopostny list pasterski J.E. Ks. Biskupa Ordynariusza, ODCh 15 (1964), nr 1-2, s. 15.

12 Wielkopostny list pasterski o uczestnictwie w życiu Kościoła, ODCh 22 (1971), nr 1-3, s. 3-12.

13 Tamże, s. 10.

14 List pasterski ks. Biskupa ordynariusza na Wielki Post 1972 roku, ODCh 23 (1972), nr 1-3, s. 8. 
Te wypowiedzi pasterza Kościoła chełmińskiego potwierdzają jego szerokie pojmowanie liturgii. Jest ona dziełem całego Chrystusa, a więc Głowy i Ciała (dotąd dominowało przekonanie, że liturgia jest sprawowana tylko przez osoby do tego delegowane, ustanowione odpowiednim obrzędem). Dokumenty soboru podkreślają, że całe zgromadzenie jest liturgiem, ale każdy według własnej funkcji (kapłaństwo ministerialne i kapłaństwo chrzcielne, jako dwa sposoby udziału w jedynym kapłaństwie Chrystusa - zob. KKK 1188).

\section{RECEPCJA WSKAZAŃ SOBORU W DIECEZJI CHEŁMIŃSKIEJ}

Biskup Kowalski nie tylko sam rozumiał zamysł soboru, nie tylko informował i nauczał o zmianach wprowadzanych $w$ liturgii, o ich pastoralnym i egzystencjalnym ukierunkowaniu, lecz również wiele z nich natychmiast wprowadzał w życie Kościoła diecezjalnego. Po zakończeniu pierwszej sesji soboru w „Orędowniku Diecezji Chełmińskiej” ukazały się praktyczne wskazania dla duszpasterstwa liturgicznego, które duszpasterze mieli wziąć pod uwagę w życiu parafialnym ${ }^{15}$. Ich znaczenie jest o tyle istotne, że zawarte tam postulaty o charakterze ogólnym zostały w kolejnych latach doprecyzowane i były publikowane jako konkretne zarządzenia diecezjalne.

W punkcie wyjścia podkreślono, że obrzędy liturgiczne nie są celem samym w sobie, ale ich celem jest włączenie człowieka w życie całego Kościoła, rozumianego jako Mistyczne Ciało Chrystusa. W tym dziele ważną rolę pełnią kapłani, którzy sprawując liturgię powinni sami żyć pełnią życia liturgicznego Kościoła. Oznacza to dwie sprawy: po pierwsze, liturgia nie ogranicza się jedynie do samej celebracji, wykonania przepisanych obrzędów, ale obejmuje także pozostałe przestrzenie życia kapłańskiego. Biskup Kowalski sprecyzował tę myśl w swojej

15 Zob. Praktyczne wskazania dla duszpasterstwa liturgicznego, ODCh 14 (1963), nr 4-6, s. 125-126. Biskupa Kowalskiego wspierała powołana przez niego 1 IV 1948 roku, na podstawie wskazań enc. Mediator Dei, Rada Liturgiczna (Concilium ad liturgicum provehendum apostolatum), a potem, na mocy Sacrosanctum Concilium (nr 44-46) Diecezjalna Komisja Liturgiczna. Jej sekretarzem był ks. Alfons Trzebiatowski, a przewodniczącym biskup ordynariusz. Zob. ODCh 4(1948), nr 2, s. 98. Ks. A. Trzebiatowski był sekretarzem i kapelanem biskupa K.M. Spletta. Po wojnie został notariuszem w kurii oraz ceremoniarzem katedralnym. Od 1 X 1947 był profesorem rytu i rubrycystyki w seminarium duchownym. W latach 1961-1972 należał do Komisji Egzaminacyjnej dla Organistów. 11 IX 1962 został egzaminatorem prosynodalnym z dziedziny liturgiki duszpasterskiej w egzaminach proboszczowskich. Od 1946 redagował Kalendarz liturgiczny (Ordo divini officii persolvendi). Wydał kilka publikacji na temat przepisów rubrycystycznych, obowiązujących przy odprawianiu mszy św. i innych nabożeństw. Zob. H. Mross, Ks. Alfons Jutrzenka-Trzebiatowski (1916-1972), w: Księga jubileuszowa 350 lat Wyższego Seminarium Duchownego w Pelplinie, red. A. Nadolny, Pelplin 2001, s. 708-709. 
odezwie na Dzień Świętości Kapłańskiej (21 VI 1963) ${ }^{16}$. Napisał tam, że liturgia i kult nie wyczerpują całej działalności kapłańskiej. Wszystkie jednak pozostałe aktywności, trudy pracy duszpasterskiej i życia kapłańskiego należy odnosić do liturgii, której ośrodkiem jest Eucharystia. Liturgia jest zbawczym dziełem Chrystusa, pamiątką Jego ofiary, a upodobniony do Niego przez chrzest i sakrament święceń kapłan powinien każde swoje działanie ukierunkowywać paschalnie, podobnie jak Zbawiciel. Po drugie, należy pogłębiać znajomość liturgii, jej ducha i wewnętrznej spójności, bowiem od tego zależy actuosa participatio wiernych.

$\mathrm{Na}$ tej podstawie sformułowano kolejne wskazania liturgiczne. Każdy kapłan powinien dobrze przygotować się do sprawowania liturgii, zarówno teoretycznie, jak i praktycznie. Pomocą ma być studium czasopism liturgicznych, które na bieżąco informują o wprowadzanych zmianach ${ }^{17}$. Natomiast bezpośrednio przed celebracją należy zapoznać się z rubrykami mszału i innych odnowionych ksiąg liturgicznych, aby ,wierni nie gorszyli się potem, że sam liturg dopiero podczas ceremonii się uczy"18. Jeśli bowiem celebrans sam nie zna struktury obrzędów i nie rozumie ich znaczenia, to z pewnością wierni tym bardziej będą jedynie obserwatorami niż uczestnikami.

Kolejne zarządzenia były adresowane do poszczególnych grup osób, które uczestniczą i celebrują święte czynności. Ponieważ wymagają one odpowiedniej służby liturgicznej, należy zapoznać posługujących na temat przebiegu całości obrzędu. Dotyczy to w szczególnej mierze współpracowników proboszcza, wikariuszy, z którymi systematycznie należy omawiać wszelkie zagadnienia, aby liturgia sprawowana w parafii była jednolita i poprawna.

Ponadto ważne jest także przygotowanie osób odpowiedzialnych za śpiew podczas liturgii (organista, schola). Muzyka i śpiew pełnią funkcję służebną wobec świętych obrzędów (zob. KL 112) i jeśli są dobrze przygotowane, pomagają wiernym w pełnym udziale. Biskup Kowalski był świadom dużej roli i wartości śpiewu liturgicznego, dlatego wydał zarządzenie, aby w każdym kościele parafialnym i filialnym została założona schola cantorum ${ }^{19}$. Zaznaczył przy tym, że taka grupa jest nie tylko jednym z najważniejszych, ale wręcz nieodzownym środkiem prowadzącym do „wzorowego przeprowadzenia odrodzenia liturgicznego" $20 \mathrm{i}$ aktyw-

16 Odezwa J.E. Ks. Biskupa Ordynariusza na XVII Dzień Świętości Kapłańskiej (21 VI 1963), ODCh 14 (1963), nr 4-6, s. 124-125.

17 Kilka lat później biskup nie tylko zachęcał duchowieństwo, ale wręcz nakładał obowiązek permanentnej formacji intelektualnej, aby „utrzymać swą wiedzę i swój poziom wychowawczy na wysokości wskazanej przez Sobór Watykański II”. Dotyczyło to także formacji liturgicznej poprzez np. prenumeratę czasopisma „Ruch Biblijny i Liturgiczny”, które wznowiło swoją działalność, czy też innych pism. Zob. Odezwa Ks. Biskupa Ordynariusza do kapłanów o obowiązku stałego doksztatcania się, ODCh 21 (1970), nr 7-9, s. 210-211.

18 Praktyczne wskazania dla duszpasterstwa liturgicznego, ODCh 14 (1963), nr 4-6, s. 125.

19 Zob. Zarzadzenie w sprawie ,, scholae cantorum”, ODCh 21 (1970), nr 10-12, s. 260-261.

20 Tamże, s. 260. 
nego uczestnictwa. W jej skład mają wchodzić przede wszystkim ludzie młodzi, a starsi o tyle, o ile są zainteresowani wzbogaceniem liturgii. O tym, jak ważny był to dla biskupa postulat świadczy fakt, że w czasie trzech miesięcy dziekani zostali zobowiązani do przeprowadzenia wizytacji („kontroli”) i zreferowania stanu realizacji tych postulatów ordynariuszowi.

Znaczenie śpiewu dla odnowionej liturgii wynikało także z innych posoborowych dokumentów, które biskup diecezjalny musiał wziąć pod uwagę we wprowadzaniu reformy liturgicznej. 5 III 1967 roku opublikowano instrukcję o muzyce w świętej liturgii Musicam sacram ${ }^{21}$. Jest ona komentarzem i interpretacją adekwatnych wskazań soborowej konstytucji o liturgii, która prezentowała jedynie ogólne kierunki reformy. Instrukcja podkreślała wysoką rangę muzyki i śpiewu liturgicznego, których celem jest oddanie chwały Bogu i uświęcenie wiernych (nr 4). W jej świetle schola cantorum ma poprawnie wykonywać właściwe części liturgii oraz wspomagać wiernych w uczestnictwie w niej (nr 19). Podkreślała także, że członkowie scholi (zespołu śpiewaków) pełnią prawdziwą funkcję liturgiczną, bowiem czynności liturgiczne są kultem Kościoła, czyli całego ludu Bożego pod przewodnictwem kapłana (nr 13).

Osobnym tematem było kształcenie organistów, którzy - szczególnie w małych parafiach - byli odpowiedzialni za to, aby wierni nie byli biernymi widzami, milczącymi obserwatorami, ale świadomie włączali się w liturgię. Działania wojenne spowodowały zawieszenie działalności Studium Organistowskiego w Pelplinie. Zostało ono reaktywowane, ponieważ uproszczona procedura przygotowania muzyków była niewystarczająca ${ }^{22}$. Program kształcenia wymagał także odpowiedniej wiedzy z zakresu liturgiki (m.in. znajomości encyklik, Konstytucji o liturgii itp.).

Praktyczne wskazania dla duszpasterstwa liturgicznego zobowiązywały również do poświęcenia większej uwagi ministrantom, aby byli wzorowo przygotowywani do bezpośredniej służby ołtarza ${ }^{23}$. Ich formacja miała być także integralna, na co wskazywać mogą inne dokumenty ordynariusza. Podkreślał on, aby ministranci byli dobrze przygotowywani duchowo. Wyrazem tego jest przystąpienie do sakramentu pokuty i pojednania, aby móc w pełni uczestniczyć w liturgii eucharystycznej ${ }^{24}$. Wspólna modlitwa (liturgiczna) i Komunia święta były często podkreślane przez biskupa Kowalskiego jako jedne z ważnych przejawów ducha odnowy liturgicznej,

${ }_{21}$ Zob. Święta Kongregacja Obrzędów, Instrukcja o muzyce w świętej liturgii „, Musicam sacram” (5 III 1967), w: Prawodawstwo muzyki kościelnej, red. A. Filaber, Warszawa 2008, s. 43-59.

22 Zob. W sprawie szkolenia i doksztatcania organistów, ODCh 22 (1971), nr 4-6, s. 115-118.

23 Zob. Praktyczne wskazania dla duszpasterstwa liturgicznego, ODCh 14 (1963), nr 4-6, s. 126.

${ }^{24}$ Zob. Diecezjalne nabożeństwo stużby ottarza (10.V.1970), ODCh 21 (1970), nr 7-9, s. 209; Diecezjalne nabożeństwo dla ministrantów, ODCh 22 (1971), nr 4-6, s. 115. 
ponieważ przez nie wyrażał się udział w misterium paschalnym Jezusa Chrystusa ${ }^{25}$. W celu pomocy duszpasterzom ministrantów organizowano w Pelplinie dni skupienia, podczas których poruszano różne tematy związane $\mathrm{z}$ formacją tej grupy (np. wychowanie do apostolstwa czy kształcenie lektorów) ${ }^{26}$.

Biskup Kowalski, realizując soborową zasadę actuosa participatio w odniesieniu do funkcji pełnionych w zgromadzeniu liturgicznym, zachęcał szczególnie do formowania lektorów, ponieważ ta funkcja ,pobudza Lud Boży bardzo skutecznie do pełnego udziału w tajemnicach Ołtarza"27. Ordynariusz dobrze rozumiał posługę lektora i nie ograniczał jej jedynie do technicznej umiejętności poprawnego czytania. Lektor rozważa i zachowuje słowo Boże, rozwija w sobie życie kontemplacyjne wnikając w bogatą treść prawd objawionych. Znajomość Pisma Świętego ma być dla niego pomocą w dialogu z ludźmi słabej wiary i z niewierzącymi. Lektorzy, kształtowani do liturgii i przez liturgię, byli uważani przez biskupa za fundament apostolstwa katolików świeckich ${ }^{28}$. Biskup zaznaczył, że lektorami mogą być starsi ministranci, inni świeccy cechujący się dojrzałością w wierze oraz osoby życia zakonnego, które mogą spełniać ten urząd w wyjątkowych wypadkach ${ }^{29}$.

Ostatni punkt wskazań liturgicznych dotyczył wychowania liturgicznego wszystkich wiernych. Nie należy ich zaniedbywać czy ignorować ich potrzeb, ale cierpliwie pouczać, wyjaśniać liturgię Mszy św. i pozostałych obrzędów, zapoznawać z ich strukturą oraz nauczać podstawowych tekstów, odpowiedzi i śpiewów liturgicznych. Celem było nie tylko przygotowanie do liturgii, ale również wychowanie poprzez liturgię do autentycznego życia chrześcijańskiego, co już we wstępie podkreślała soborowa Konstytucja o liturgii (zob. KL 1) $)^{30}$.

\section{RECEPCJA NOWEGO „ORDO MISSAE” W DIECEZJI CHEEMIŃSKIEJ}

Nowe obrzędy Mszy św. zostały ogłoszone w Wielki Czwartek (3 IV 1969) łącznie z Konstytucją Apostolską Missale Romanum i Institutio generalis Missalis Romani ${ }^{31}$. Zawierały wiele zmian wynikających z Konstytucji o liturgii oraz

25 Zob. np. Wielkopostny list pasterski, ODCh 21 (1970), nr 1-4, s. 15; Odezwa Ks. Biskupa ordynariusza na Wielkanoc 1972 roku, ODCh 23 (1972), nr 4-7, s. 158.

26 Zob. Skupienie dekanalnych duszpasterzy stużby ottarza, ODCh 19 (1968), nr 3-6, s. 143.

27 Zob. Odezwa Ks. Biskupa Ordynariusza do kapłanów w sprawie kształcenia lektorów, ODCh 22 (1971), nr 4-6, s. 113-114.

28 Tamże, s. 114.

29 Należy wspomnieć, że trzecia instrukcja wykonawcza (Liturgica instaurationes z 5 IX 1970) pozwalała kobietom pełnić funkcję lektora (nr 7).

30 Praktyczne wskazania dla duszpasterstwa liturgicznego, ODCh 14 (1963), nr 4-6, s. 126.

31 Zob. Cz. Krakowiak, Papież Pawet VI i nowe Ordo Missae (1969), „Teologiczne Studia Siedleckie" XII (2015), s. 89. 
z instrukcji wykonawczych. Zgodnie z decyzją Konferencji Episkopatu Polski nowe Ordo Missae zaczęło obowiązywać od pierwszej niedzieli Adwentu 1970 roku. Jego wprowadzenie zostało poprzedzone w diecezji chełmińskiej odpowiednim przygotowaniem zarówno duchowieństwa, jak i wiernych. Prezbiterzy (diecezjalni i zakonni) uczestniczyli w konferencjach rejonowych oraz $\mathrm{w}$,Skupieniu posoborowym”, gdzie przedstawiano podstawowe zmiany i aktualne obrzędy Mszy św. ${ }^{32}$. Poza tym pomocą służyły publikacje dokumentów Stolicy Apostolskiej w urzędowym piśmie diecezji33. Szczegółowe zmiany były ponadto publikowane systematycznie, w miarę ukazywania się kolejnych instrukcji wykonawczych ${ }^{34}$.

W „Orędowniku Diecezji Chełmińskiej” ukazywały się ponadto inne materiały, przygotowane przez Diecezjalną Komisję Liturgiczną, której przewodniczącym był biskup ordynariusz. Przede wszystkim instrukcja, która w przejrzystej formie (tabela) przedstawiała przebieg odnowionej Mszy św. ${ }^{35}$. Po dopuszczeniu przez Episkopat Polski przekładu nowego Ordo Missae (5 V 1970), które zaczęło obowiązywać od pierwszej niedzieli Adwentu $1970^{36}$, zasady nowej liturgii zostały podane w diecezjalnym kalendarzu liturgicznym ${ }^{37}$. Przygotowanie wszystkich wiernych odbywało się poprzez wykłady $i$ katechezy liturgiczne przygotowane przez ks. Bolesława Koseckiego ${ }^{38}$ oraz materiały homiletyczne publikowane

32 Zob. Diecezjalne skupienie posoborowe duchowieństwa, ODCh 21 (1970), nr 1-4, s. 85.

33 Należą do nich m.in.: Konstytucja Apostolska ,Missale Romanum” promulgująca Mszał Rzymski odnowiony z polecenia Soboru Powszechnego Watykańskiego II, ODCh 21 (1970), nr 1-4, s. 18-20; Dekret i oświadczenie w sprawie nowego „Porzadku odprawiania Mszy świętej”, ODCh 21 (1970), nr 1-4, s. 21; Instrukcja Św. Kongregacji dla Kultu Bożego o stopniowym wprowadzaniu w życie Konstytucji Apostolskiej „Missale Romanum”, ODCh 21 (1970), nr 1-4, s. 70-73; Porzadek Czytań Mszalnych, ODCh 21 (1970), nr 5-6, s. 102-116.

34 Zob. Po publikacji Inter oecumenici (26 IX 1964): Innowacje we Mszy św., ODCh 16 (1965), nr 1-2, s. 42-47; po publikacji Tres abhinc annos (4 V 1967): Ordo Missae wedtug nowych rubryk obowiazujacych od dnia 29 czerwca 1967 roku, ODCh 18 (1967), nr 6-8, s. 194-196.

35 Zob. Porzadek czynności celebransa i wiernych we Mszy św. wedlug nowego Mszatu łacińskopolskiego", ODCh 20 (1969), nr 1-4, s. 53-59. Należy dodać, że Mszał łacińsko-polski został wydany w 1968 roku w Paryżu i był zasadniczo Mszałem Rzymskim Piusa V, ale na nowo zredagowanym i uwzględniającym dotychczasowe wskazania soboru. Msza św. z czynnym udziałem wiernych była sprawowana w j. polskim (poza Kanonem Mszalnym), a bez udziału wiernych w j. łacińskim. Zob. List Biskupów Polskich w sprawie wprowadzenia Mszału łacińskopolskiego, ODCh 19 (1968), nr 10-12, s. 254-256. Zob. także: S. Araszczuk, Recepcja konstytucji o liturgii w Kościele w Polsce, „Liturgia Sacra” 19 (2013), nr 2, s. 343.

36 Zob. Poprawki w polskim ,Ordo Missae”, ODCh 21 (1970), nr 10-12, s. 259-260.

37 Zob. Ordo Divini Officii Persolvendi Missaeque Celebrandae in usum Dioecesis Culmensis pro anno domini 1971, Pelplin 1970.

38 Ks. B. Kosecki studiował w Instytucie Katolickim w Paryżu oraz w Papieskim Instytucie Liturgicznym w Rzymie. Towarzyszył bp. Kowalskiemu jako sekretarz w Rzymie podczas soboru, a następnie wrócił do diecezji i zajmował się odnową liturgii w diecezji. W 1968 r. został członkiem Diecezjalnej Komisji Liturgicznej. Zob. S. Człapa, Ks. Bolesław Kosecki (1917-1986), w: Księga 
w „Bibliotece Kaznodziejskiej”39. Poza tym w diecezjalnych periodykach (w „Orędowniku Diecezji Chełmińskiej”, w kalendarzu liturgicznym) publikowano cyklicznie nowy „Porządek czytań mszalnych”, który nie ukazał się jeszcze w całości w języku polskim ${ }^{40}$.

Zgodnie z zaleceniami Vaticanum II przywrócono po Ewangelii i homilii dawną modlitwę wiernych, szczególnie w mszach niedzielnych i świątecznych (zob. KL 53). W 1966 roku ukazała się księga liturgiczna De oratione communi seu fidelium omawiająca naturę, strukturę i znaczenie tej modlitwy oraz podająca jej wzorcowe przykłady. Polskie thumaczenie księgi pojawiło się dopiero w 1970 roku, dlatego biskup chełmiński zarządził, że na terenie diecezji modlitwa powszechna jest dozwolona tylko po uzyskaniu specjalnego pozwolenia ordynariusza po uprzednim przedłożeniu jej tekstu ${ }^{41}$. W Orędowniku publikowano jednak przykładowe, wzorcowe modlitwy powszechne na wybrane obchody, które miały być pomocą dla duszpasterzy w jej wprowadzaniu ${ }^{42}$.

Podobnie przedstawiała się sytuacja z koncelebracją Mszy św. Dotąd możliwa jedynie w ściśle określonych okolicznościach, została rozszerzona ${ }^{43}$. Biskup Kowalski, stosując się do aktualnych wskazań zarządził, że w diecezji chełmińskiej koncelebracja jest dozwolona jedynie za specjalnym pisemnym pozwoleniem ordynariusza $^{44}$. W ten sposób okazywał się on roztropnym pasterzem, unikającym niebezpiecznego pośpiechu i nowinkarstwa, a jednocześnie posiadającym szerokie perspektywy czynnego udziału w liturgii, która jest epifanią Kościoła.

jubileuszowa. 350 lat Wyższego Seminarium Duchownego w Pelplinie, red. A. Nadolny, Pelplin 2001, s. 520-522.

39 Zob. Nowe obrzędy liturgii mszalnej, ODCh 21 (1970), nr 10-12, s. 261.

40 Zob. Dodatek: Czytania mszalne podczas Mszy św. żałobnych (stron 32), ODCh 22 (1971), nr 1-3, s. 1-32; Lekcjonarz na dni powszednie Adwentu, ODCh 19 (1968), nr 1-2, s. 40-46.

${ }_{41}$ Zob. Porzadek czynności celebransa $i$ wiernych we Mszy św. wedtug nowego Mszalu tacińskopolskiego", ODCh 20 (1969), nr 1-4, s. 59. Por. Porządek czynności celebransa $i$ wiernych we Mszy św., ODCh 18 (1967), nr 4-5, s. 119.

42 Na tydzień misyjny: ODCh 19 (1968), nr 7-9, s. 223-224; na zakończenie Roku Wiary: ODCh 19 (1968), nr 3-6, s. 140-141; na urocz. 3 maja 1968: ODCh 19 (1968), nr 3-6, s. 130; na niedzielę Dobrego Pasterza (dzień modlitw o powołania): ODCh 20 (1969), nr 5-8, s. 131; na urocz. 3 maja 1970: ODCh 21 (1970), nr 7-9, s. 203; na zakończenie roku szkolnego: ODCh 22 (1971), nr 7-10, s. 161.

43 Instrukcja Inter Oecumenici (26 IX 1964) zezwoliła kapłanom na koncelebrację Mszy św. według mającego się dopiero ukazać nowego obrzędu koncelebry, który został ogłoszony w dekrecie Ecclesiae semper (7 III 1965). Zob. Cz. Krakowiak, Koncelebracja Mszy świętej 50 lat po Sacrosanctum Concilium, „Roczniki Teologiczne” 61 (2014), z. 8, s. 46.

44 Zob. Porządek czynności celebransa i wiernych we Mszy św., ODCh 18 (1967), nr 4-5, s. 119. 


\section{PODSUMOWANIE}

Celem soborowej reformy liturgicznej była odnowa Kościoła i życia chrześcijańskiego wiernych (zob. KL 1). Sobór nie podał jednak gotowych rozwiązań aktualnych problemów, lecz jedynie wskazał kierunki ich rozwiązywania, które następnie były precyzowane w kolejnych dokumentach. W tym kontekście biskup Kazimierz Józef Kowalski stał się prawdziwym promotorem posoborowej odnowy liturgicznej w diecezji chełmińskiej. Jako uczestnik obrad soborowych i konsultor Komisji Liturgicznej dobrze rozumiał założenia i istotę podejmowanych prac. Jako ordynariusz był zarówno strażnikiem Tradycji Kościoła, wyrażającej się w lex orandi, lecz jednocześnie mistagogiem, który konsekwentnie wprowadzał powierzoną mu wspólnotę diecezjalną w posoborową rzeczywistość Kościoła objawiającego się w reformowanej liturgii.

\section{Bibliografia}

Araszczuk S., Recepcja konstytucji o liturgii w Kościele w Polsce, „Liturgia Sacra" 19 (2013), nr 2, s. 337-355.

Bielawny K., Udziat biskupów polskich w obradach Soboru Watykańskiego II, „Studia Ełckie” 11 (2009), s. 103-122.

Człapa S., Ks. Bolesław Kosecki (1917-1986), w: Ksiega jubileuszowa. 350 lat Wyższego Seminarium Duchownego w Pelplinie, red. A. Nadolny, Pelplin 2001, s. 520-522.

Diecezjalne nabożeństwo dla ministrantów, ODCh 22 (1971), nr 4-6, s. 115.

Diecezjalne nabożeństwo stużby ottarza (10.V.1970), ODCh 21 (1970), $\mathrm{nr}$ 7-9, s. 209.

Diecezjalne skupienie posoborowe duchowieństwa, ODCh 21 (1970), nr 1-4, s. 85 .

Dodatek: Czytania mszalne podczas Mszy św. żałobnych (stron 32), ODCh 22 (1971), nr 1-3, s. 1-32.

Innowacje we Mszy św., ODCh 16 (1965), nr 1-2, s. 42-47.

J.E. Ks. Biskup Ordynariusz mianowany Konsultorem Komisji Soborowej dla spraw Świętej Liturgii, „Orędownik Diecezji Chełmińskiej” 11(1960), nr 11-12, s. 307.

Krakowiak Cz., Koncelebracja Mszy świętej 50 lat po Sacrosanctum Concilium, „Roczniki Teologiczne” 61 (2014), z. 8, s. 43-55.

Krakowiak Cz., Papież Pawet VI i nowe Ordo Missae (1969), „Teologiczne Studia Siedleckie" XII (2015), s. 83-98. 
Krzystek A., Przedsoborowe ,,drogi” do generalnej reformy liturgicznego Soboru Watykańskiego II, „Colloquia Theologica Ottoniana” 1 (2015), s. 7-24.

Lekcjonarz na dni powszednie Adwentu, ODCh 19 (1968), nr 1-2, s. 40-46.

Liedtke J.E., Miles Christi - Ksiądz Biskup Kazimierz Józef Kowalski, ordynariusz diecezji chetmińskiej, ,Studia Elbląskie” XVI (2015), s. 23-41.

List pasterski ks. Biskupa ordynariusza na Wielki Post 1972 roku, ODCh 23 (1972), nr 1-3, s. 6-10.

Mross H., Ks. Alfons Jutrzenka-Trzebiatowski (1916-1972), w: Księga jubileuszowa 350 lat Wyższego Seminarium Duchownego w Pelplinie, red. A. Nadolny, Pelplin 2001, s. 708-709.

Mylik M., Biskup Kazimierz Józef Kowalski. Z dziejów odnowy neoscholastyki polskiej, Pelplin 2008.

Nowe obrzędy liturgii mszalnej, ODCh 21 (1970), nr 10-12, s. 261-262.

Odezwa J.E. Ks. Biskupa Ordynariusza na XVII Dzień Świętości Kapłańskiej (21 VI 1963), ODCh 14 (1963), nr 4-6, s. 124-125.

Odezwa Ks. Biskupa Ordynariusza do kapłanów o obowiązku stałego doksztatcania sie, ODCh 21 (1970), nr 7-9, s. 210-211.

Odezwa Ks. Biskupa Ordynariusza do kapłanów w sprawie kształcenia lektorów, ODCh 22 (1971), nr 4-6, s. 113-114.

Odezwa Ks. Biskupa ordynariusza na Wielkanoc 1972 roku, ODCh 23 (1972), nr 4-7, s. 158.

Ordo Divini Officii Persolvendi Missaeque Celebrandae in usum Dioecesis Culmensis pro anno domini 1971, Pelplin 1970.

Ordo Missae wedtug nowych rubryk obowiązujących od dnia 29 czerwca 1967 roku, ODCh 18 (1967), nr 6-8, s. 194-196.

Orędzie J.E. Ks. Biskupa Ordynariusza na Nowenne przed Soborem, ODCh 13 (1962), nr 9-10, s. 287-288.

Pokłosie minionych sesji soborowych. Przemówienie J.E. Ks. Biskupa Ordynariusza, wygłoszone w Radio Watykańskim dnia 25 listopada 1964 r., ODCh 15 (1964), nr 11-12, s. 281-283.

Poprawki w polskim „, Ordo Missae”, ODCh 21 (1970), nr 10-12, s. 259-260.

Porzadek czynności celebransa i wiernych we Mszy św. wedtug nowego Mszatu tacińsko-polskiego", ODCh 20 (1969), nr 1-4, s. 53-59.

Porządek czynności celebransa i wiernych we Mszy św. wedtug nowego Mszału tacińsko-polskiego, ODCh 20 (1969), nr 1-4, s. 53-59.

Porzadek czynności celebransa i wiernych we Mszy św., ODCh 18 (1967), nr 4-5, s. 114-119.

Praktyczne wskazania dla duszpasterstwa liturgicznego, ODCh 14 (1963), nr 4-6, s. 125-126.

Przemówienie radiowe J.E. Ks. Biskupa Ordynariusza Kazimierza Józefa Kowalskiego w dniu 19 listopada 1962 roku, ODCh 14 (1963), nr 1-3, s. 16-19. 
Skupienie dekanalnych duszpasterzy stużby oltarza, ODCh 19 (1968), nr 3-6, s. 143.

Stefański J., Redakcja „Konstytucji o liturgii świętej” przełomem odnowy życia religijnego w Kościele (1963-2003), „Seminare” 21 (2005), s. 189-201.

Święta Kongregacja Obrzędów, Instrukcja o muzyce w świętej liturgii „,Musicam sacram" (5 III 1967), w: Prawodawstwo muzyki kościelnej, red. A. Filaber, Warszawa 2008, s. 43-59.

W sprawie szkolenia i doksztatcania organistów, ODCh 22 (1971), nr 4-6, s. $115-118$.

Wielkopostny list pasterski J.E. Ks. Biskupa Ordynariusza, ODCh 14 (1963), nr 1-3, s. 19-22.

Wielkopostny list pasterski J.E. Ks. Biskupa Ordynariusza, ODCh 15 (1964), nr 1-2, s. 13-15.

Wielkopostny list pasterski o uczestnictwie w życiu Kościoła, ODCh 22 (1971), nr 1-3, s. 9-12.

Wielkopostny list pasterski, ODCh 17 (1966), $\mathrm{nr} 4-5$, s. 19-22.

Wielkopostny list pasterski, ODCh 21 (1970), nr 1-4, s. 14-17.

Zarzadzenie w sprawie ,scholae cantorum”, ODCh 21 (1970), nr 10-12, s. $260-261$.

Zieliński Z., Sobór Watykański II. Udziat Polaków, w: 50. rocznica Soboru Watykańskiego II. Sympozjum naukowe. Przemyśl, 8 XI 2012, oprac. J. Łobos, Przemyśl 2013, s. 31-47. 